\title{
Islamic Populism on 212 Movement
}

\author{
Dr. Yuanita Aprilandini Siregar, M.Si ${ }^{1}$, Dea Bhakti Pratama, S.Sos ${ }^{2}$, Dr. Ikhlasiah \\ Dalimunthe, $\mathrm{M}_{\mathrm{Si}}{ }^{3}$ \\ \{Yuanita-Apriliandini@unj.ac.id ${ }^{1}$,deabhakti16@gmail.com², ikhlasiah-dalimoenthe@unj.ac.id ${ }^{3}$ \} \\ Universitas Negeri Jakarta ${ }^{1,2,3}$
}

\begin{abstract}
The purpose of this study to describe the 212 movement as a phenomenon of Islamic populism based on socio-religious movements followed by various Islamic organizations and their contradictions with other Islamic organizations. The 212 movement was followed by various Islamic groups and organizations. Participation was based on various forms of motivation, demands, principles and organizational ideology. In addition, there are contradictions among religious organizations regarding their perceptions of the 212 movement. Pros and cons discourse were based on the interpretations of ideology and organizational principles. Mass mobilization and Islamic populism were transform this movement in to the populist movement. There are correlation between social movements and Islamic populism as an evidenced by the finding of chains of equivalens and empty signifiers which have implications for the formation of political frointer in the 212 Islamic populism movement.
\end{abstract}

Keywords: 212 Movement; Chains of Equivalens; Islamic Populism

\section{Introduction}

The transformation from collective action into social movement are caused by internal and external factors. Internal factors related to the individual motivation, perception, ideology and affiliation of actors. In additional, external factors are related to the similiarity of identity, sexual orientation, and social class. Islamic politics and Islamic social movements could be understood as populist responses to social contradictions (Hadiz, 2016:33). This can be argued there is a correlation between organization and construction of meaning on religious values , producing a populist social movement. Populism required dichotomous division of society into two group, one presenting the claim of the truth and also an opposite-antagonistic claimed. The purpose of this study to describe the 212 movement as a phenomenon of Islamic populism based on socio-religious movements followed by various Islamic organizations and their contradictions with other Islamic organizations.

The stand point of this study regarding polarization as the body of social movement from Ernesto Laclau's perspectives. According to Laclau, populism are political construction of the unification of homogeneous demands or aspirations on heterogeneous society. The academic discourse between unfulfilled people's demands through unresponsive elit power (Margiansyah, 2019: 50) . The experience of Argentine Peronism was the background for Laclau's thoughts on politics, including his theories on antagonism and populism (Marchart, 2018: 109). Populism departs from the existence of a momentum based on demands and 
interests in the form of social demands. Although each group was using identity's symbols, it's part from their political agendas.

These categories of claims may change through multiple transitions. Transition here is meant to be a relationship that articulates some unfulfilled demands and interest (Laclau, 2005:72). Then these demands are accumulated with other demands, in fact in these demands there is a chain of equivalence, namely situations that are equal in terms of the meaning of the demands. Internal border formation was born, dichotomized by the local political spectrum through the emergence of an equivalence chain of unfulfilled demands. Right at this point the claim turns into a particular claim based on the merging of demands into singularities and popular demands (Laclau, 2005:73).

Hadiz's research shows that the socio-economic basis and political nature producing diversity issues and agendas on Islamic populism in Egypt, Turkey and Indonesia (Hadiz, 2016: 20). Populism is a form of electoral strategy for parties to held power by paying attention to political momentum (Barr, 2019:44). Populism is motivated by the failure of democratic representation and the weak alignment of parties with voters. The success of populism in Latin America such as Venezuela resulted in the Bolivarian movement which eventually led to radical political change (Bornschier, 2019: 203). Meanwhile, populism in Belgium arises due to the dissatisfaction of native with the political establishment by traditional parties producing Vlaams Block party, represent the voice of the indigenous people of Belgium (Paniza, 2005 : 230). Furthermore, research on Islamic populism in the Indonesian context is an electoral mobilization tool that caused by Islamic groups still on the periphery of political constellations (Mudhoffir, 2017: 55). Mudhoffir also explained populism as a form of ill-liberal democracy because it produce fragmentation when it is used as a political agendas to support or rejected the Perppu Ormas. (Mudhoffir, 2020: 119-120).

This study used qualitative method. The researchers captured the phenomenon of the 212 movement involving various religious organizations such as FPI, Persis and Al-Irsyad. The researcher also doing interview with the contradiction group that disagreed with the 212 movement, namely the Jamaah Tabligh and the Salafis. Data collection from this research using a snowball technique. Informan for this research divided into two cateogries : informants with organizational backgrounds who are pros and cons on 212 movement. Reseracher also conducted indepth interview with informants who have directly participated on 212 movement, and their organizational leader.

\section{Results and Discussions}

\subsection{Islamic Populism Movement As Chains of Equivalens}

Particularistic elements are found in the emergence of chain of equivalens in the GNPF MUI which consists of cross-member Islamic organizations. As evidenced in this analysis are three organizations that simultaneously build the internal structure of populism through the chain of equality relations. The three Islamic organizations that are equivalently related in the context of this study include FPI, Persis and Al-Irsyad Al-Islamiyyah. There are heterogeneity and segmentation in principle, ideology and activities in terms of the participation of Islamic organizations in the 212 movement incorporated in the GNPF MUI.

It is known that FPI's particularity is contained in its ideology, principles and activities. The principles and ideology adopted by FPI embodied in the concept of "Rumah Bersih Aswaja". The manifestation of the existence of this principle is to clean our state, the Rpublic 
of Indonesia from the distortion of the Ahlus Sunnah Wal Jama'ah values. The implementation of "Rumah Bersih Aswaja" include on three fields : the

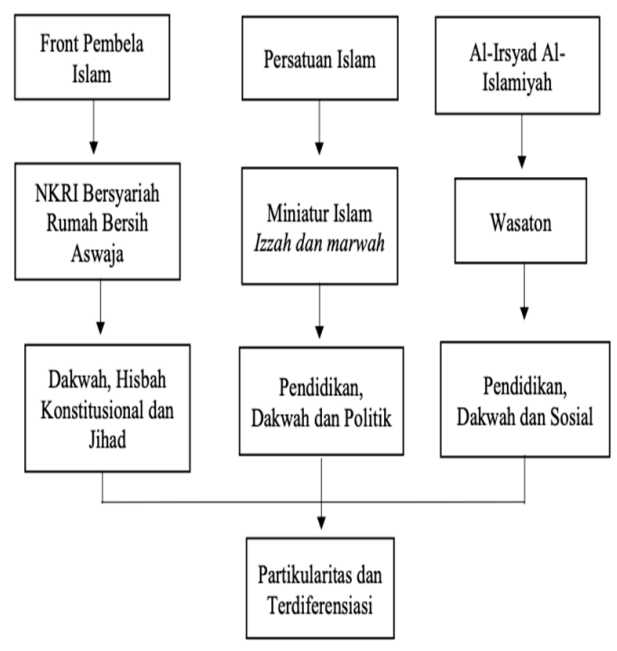

Fig. 1. Particularity Organization on 212 Movement

Activity of da'wah, the constitutional hisbah and the practice of jihad. The forms of activities of the FPI organization to discharge prostitution and gambling places and also liquor factories that are included in the hisbah struggle field. Majlis Ta'lim which discusses modern issues such as LGBT and liberalism issues are alsos to discharge by FPI in the name of hisbah.

The particularity of Persis came the ideology and principles based on an Aqidah in the Qur'an and Sunnah. Exactly has the principle that the Qur'an and Sunnah must be implemented in everyday life as a miniature form of Islam. The obligation to maintain izzah and marwah that must be held by Persis members. The meaning for this terminology are maintaining the honor of Islam, protecting and defending the guidance of Muslims, the holly Qur'an and Sunnah. Persis is also engaged in education, da'wah and politics. In the field of education, Persis has established a pesantren being part of their da'wah. Persis has a goal to abolish and straighten out all forms of takhayul, bid'ah dan kurofa . There are political disposition such as recruitmen for new member to appear as the driving force of the organization. Both as managers or leaders (tasykil) of the organization, as well known as the public officials through bidgar siasah .

The third particularity from the Al-Irsyad Al-Islamiyah organization. Al-Irsyad's particularity have been known on the concept of wasaton principles. The understanding of wasaton remarked the position and location of Al-Irsyad's ideology. Practically it has the meaning of moderate standpoint, neither left nor right. The next principle talks about prohibitions from the practice of takhayul, bid'ah dan kurofa. Al-Irsyad also engaged wihtin educational program, da'wah, health and social activities.

\subsection{Discursive Relations and Hegemonic Struggle}


The discursive relation of elites who are religious figures in Islamic organizations forms a polarization on the existence of elements of universality over something particular. FPI religious leaders are related to religious leaders Persis and Al-Irsyad, all of them have discussions about the same demands. FPI religious leaders Habib Rizieq and Habib Syafiq talked about the constitutional jihad in the 212 movement. While Persis, namely Salahuddin and Ihsan El-Haq talked about the necessity to maintain and defend the izzah and dignity of Islam and the Qur'an, and Al-Irsyad through the construction of Ustadz Fahmi Bahreys, Ustads Baraja and Abdullah Elli spoke about brought izzah and marwah to bring Ahok into court and justice immediately.

Discursive relations exist among the three elite religious figures from Islamic organizations. This relationship is ultimately manifested in a polarized hegemonic struggle in the chain of allegiance. This is based on the similarity of demands and agendas which ultimately lead to the chains of equivalens. The existence of equal demands has consequences for the formation of a new identity that transcends particularities between organizations manifested in discursive relations between antagonistic elites in the 212 movement.

The chain of equivalen that is built in discursive relations through elites and Islamic organizational figures forms an embryo of populism, by which the internal structure of populism are being maintaned. To find nodal points in the context of the 212 movement manifested in the formation of a new identification within the Gerakan Nasional Pengawal Fatwa MUI (GNPF MUI). The transformation of the empty signifier on the discursive relation that was proven over the formation of the GNPF MUI were the result of a hegemonic struggle that functions to oppose the operative order. These forms of polarization between their internal social bodies comparing to oppodite gorups. Identification of the common enemy and also the identification of the alliance in it has a universal element. 


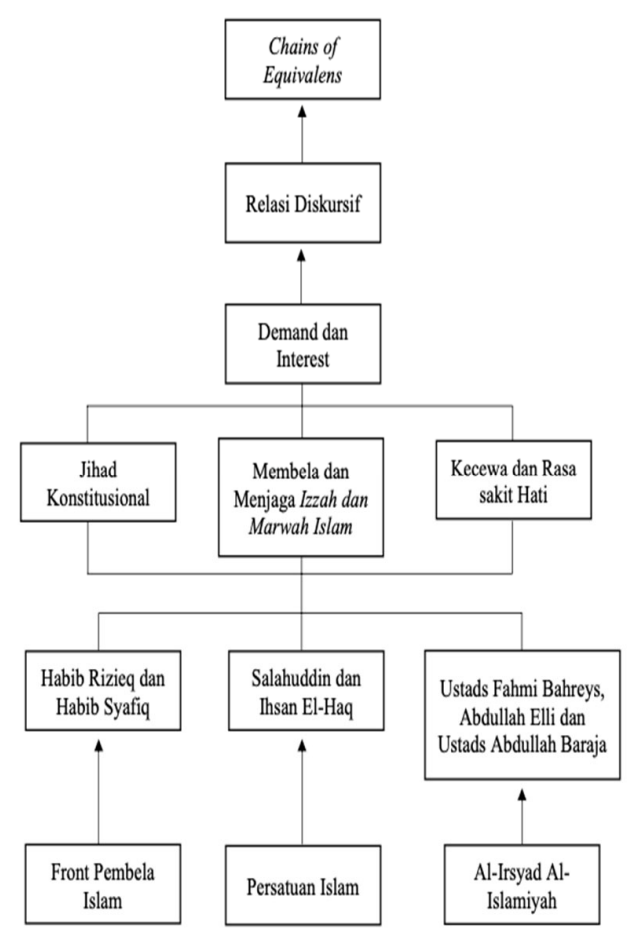

Fig. 2. Intergroup Discursive Relations

This is some crucial point that formulated a claim and nodal point, because it is the stability of universality of particular sacrifice effort among Islamic organizations. The GNPF MUI is known to have an agenda in the form of importunate Ahok's trial as a religious condempt, removing Ahok as Governor of DKI Jakarta and vocalize Muslim leaders for the electoral. All of them are particularistic efforts and the result of a chain of equivalens. The declaration of GNPF MUI is an empty identification well capable to absorb various particularities between Islamic organizations that cannot be separated from the hegemonic struggle : FPI, Al-Irsyad and Persis under the banner of GNPF MUI to determine a certain agendas.

\subsection{Populism Movement as A Political Movement}

The populism movement 212 which presents the GNPF MUI as a populist organizational structure creates a political frontier against operative relations, namely relations of subordination that give rise to antagonism. The operative relationship on 212 movement is Ahok as the protagonist elite and his supporting elite based on conflicting Islamic organizations, namely Jamah Tabligh and the Salafi. The presence of the 212 populism movement, which contained antagonism in the social body have been arise based on the existence from operative relations.

The statement from Ahok, regarding Al-Maidah : 51, was counter attack to the objective structure. It has implication for the emergence of a reflective awareness to demand and the equivalent agenda that Ahok must be brought to the court. The emerging 212 movement also 
had an implication for the creation of a political frontier. The populism movement is manifested from the existence of an equality of identification to the new identity formation. The emergence of chains of equivalens and empty signifier creates a claim at certain nodal point which result in several agendas and demands. The antagonistic elite contesting discursive relations with each other in the name of GNPF MUI established the Islamic populism.

The unification of various Islamic organizations in the GNPF MUI is an attempt to transcend the previously constructed differences to the emergence of a new identification of elite opponents, the creation of opposition within the social body. Then, at the level of the elite protagonist, namely Ahok who manifest the emergence of operative relations in the social body.

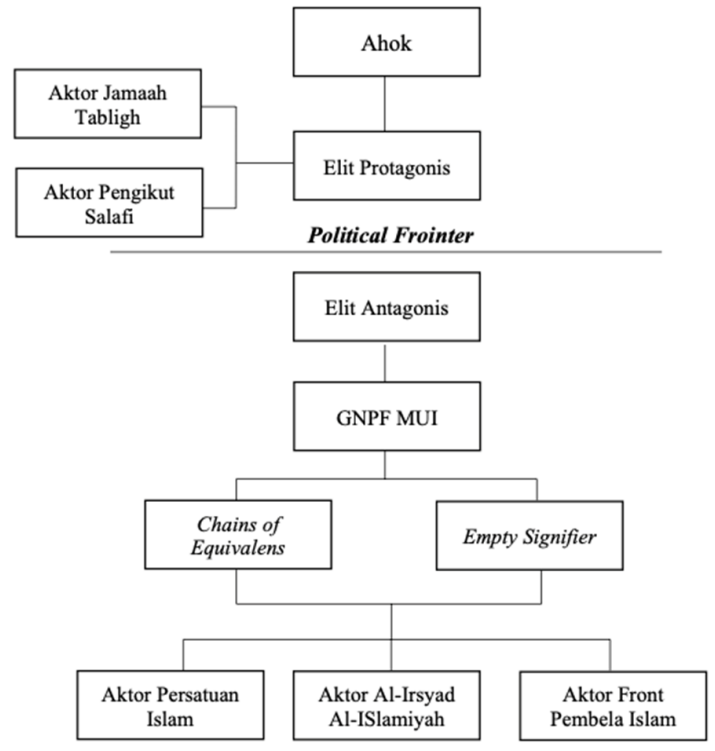

Fig. 3. Populism Movement 212

Political frointer in the 212 populism movement shows that there is an antagonism constructed by various elites in the social body, including the Tablighi Jamaat there is Ustads Ican or commonly called Gus Ican and in the Salafis themselves there are Ustads Novtriadi, the two elites internalize a conflict through principles, ideologies and organizational activities that judge that they do not participate in the 212 movement and pursued their members not to attend the 212 movement. Jamaah Tabligh and Salafi position as supporting the protagonist, but both cannot escaped the shackles of antagonism of the 212 movement in the social body

Polarization in the economic body includes the rise of the people's economy through the formation of the 212 Sharia Cooperative which was founded by Muslim leaders as an implementation of the spirit of Action 212 which is full of Islamic brotherhood. This spirit is then manifested in the effort to make the Sharia Cooperative 212 a forum for economic struggle to achieve the economic independence of Muslims. In fact, the Sharia 212 movement has obtained legal legitimacy from the government through the issuance of the Decree of the Minister of Cooperatives and Small and Medium Enterprises No. 
003136/BH/M.UMKM.2/I/2017 issued by the Ministry of Cooperatives and SMEs on January 19, 2017.

There are several economic commodity products that are distributed, such as the emergence of 212 mart as a representation of the Muslim economy. 212 mart, 212 mineral water, 212 mobile sharia cooperatives and community economic development waqf are economic manifestations of the 212 populism movement which has been successful and has succeeded in creating chain of equivalens as the main prerequisite for populism.

Polarization in the political body including the emergence of the 212 alumni presidium which is an organization that was institutionalized after 212. The Alumni Presidium has several manifestations such as Ijtima Ulama to recommend a National Leader manifested by several ulama from across mass organizations who are members of 212 movement. Ijtima Ulama playing important a role for future political steps for ulama, activists and leaders to take the opposition with political parties. They were participated in discussing further political steps after the 2019 presidential election. Racial and religious issues were used by potential rulers and became an instrument to gain power in the presidential electoral.

\section{Conclusion}

This study was conducted to understand the relations of various Islamic religious organizations which are the social basis of the emergence of the populism movement 212. The focus of the research is on the phenomenon of discursive relations to the hegemonic struggle between Islamic organizations to form an internal populism structure. Political frontiers and dichotomy between various elites also fill the spaces of antagonism in the 212 movement.

The social basis of the internal structure of populism in the 212 movement consists of various Islamic organizations that have variety of ideology, principles and activities. The internal structure based on populism include FPI, Persis and Al-Irsyad and have their respective actors in the internal structure of populism. Actors in the three organizations eventually formed alliances over discursive relations which eventually formed a new identification, namely GNPF MUI. Thus, the GNPF MUI is a new identification that is the main actor of the populism movement 212

In the phenomenon of the 212 populism movement, Islam becomes a stock of knowledge at the level of human intersubjective structure. The position of religious narrative (Islam) in the 212 movement becomes an element that contains two elements at once, namely, as particularity as well as universality and is used as a construction for the formation of chain of equivalens in populist organizations and populism embryos. Antagonism which is a condition for the formation of populism appears based on the existence of an operative relationship by Ahok which is constructed in such a way by populist actors which ultimately raises a reflective awareness of the situation being oppressed.

The Islamic populism of the 212 movement is also a challenge as well as a potential resource for the realization of radical democracy. Populism is neither a form of the highest ideal of democracy nor its enemy, but it is a reflection where democracy can reflect on itself and find out about and what is lacking and what to strive for. Therefore, populism can be a great force for democracy and society depending on the demands and agenda to be fought for, because populism is a strategy with which it can be used for any purpose and intention.

\section{References}


[1] Djuyandi, Yusa, dkk. 2019. "Strategi Kampanye Sudrajat-Syaikhu Mendapat Dukungan Masa Populisme Islam Dalam Pilgub Jawa Barat.” Journal of Political Issues (2018) I:1.

[2] Juru, Ignasius Jaques. 2010. "Radikalisasi Pluralisme sebagai Usaha Pengarusutamaan Politik Agonistik.” Jurnal Ilmu Sosial dan Ilmu Politik 14:2.

[3] Kusmanto, Thohir Yuli. 2017. "Gerakan Sosial Keagamaan pada Komunitas Urban: Studi Gerakan Pengajian Ahad Pagi.” Jurnal Sosiologi Walisongo 1:1

[4] Kusumo, Rangga. 2019. "Populisme Islam di Indonesia: Studi Kasus Aksi Bela Islam oleh GNPF-MUI Tahun 2016-2017.” Jurnal Politik 4:1.

[5] Margiansyah , Defbry. 2019. "Populisme di Indonesia Kontemporer: Transformasi Persaingan Populisme dan Konsekuensinya Dalam Dinamika Kontestasi Politik Menjelang Pemilu." Jurnal LIPI 16:1.

[6] Mudhoffir, Abdil Mughis, Diatyka Widya Permata Yasih dan Luqman-nul Hakim. 2017. "Populisme dan Tantangan Demokrasi di Indonesia." Jurnal Prisma 36:3

[7] Barr, Robert R. 2019. Populism as a Political Strategy. New York: Routledge Taylor and Francis Group.

[8] Bornschier, Simon. 2019. Populist Success in Latin America and Western Europe Ideational and Party System Centered Explanations. New York: Routledge Taylor and Francis Group

[9] Critchley, Simon And Oliver Marchart, 2004. Laclau a Critical, New York: Routledge

[10] Hadiz, Vedi R. 2016. Islamic Populism in Indonesia and the Middle East. United Kingdom: Cambridge University Press.

[11] Laclau, Ernesto and Chantal Mouffe, 2001. Hegemony and Socialist Strategy Towards Radical Democratic Politics, New York: Verso

[12] Laclau, Ernesto, 2005. On Populist Reason, New York: Verso.

[13] Marchart, Oliver, 2018. Thinking Antagonism Political Ontology After Laclau, United Kingdom: Edinburgh University Press Ltd.

[14] Mouffe, Chantal. 1992. Dimensions Of Radical Democracy. New York: Verso.

[15] Mouffe, Chantal. 2000. The Democratic Paradox. New York: Verso.

[16] Panizza, Francisco. 2005. Populism and Mirror of Democracy. New York: Verso.

[17] Mudhoffir, Abdil Mughis. 2020. "Islamic Populism and Indonesia's illiberal Democracy. " in Democracy in Indonesia. Singapore: ISEAS Publishing. 